\title{
UJI AKTIVITAS ANTIOKSIDAN EKSTRAK KARANG LUNAK Klyxum Sp YANG DIKOLEKSI DARI DESA TUMBAK KECAMATAN POSUMAEN MINAHASA TENGGARA
}

\author{
Elur Lonteng ${ }^{1)}$, Adithya Yudistira ${ }^{1)}$, Defny Wewengkang ${ }^{1)}$ \\ ${ }^{1)}$ Program Studi Farmasi FMIPA UNSRAT Manado, 95115
}

\begin{abstract}
Soft Coral Klyxum sp.. is a rich sources in bioactive compounds such as terpenoids, steroids, and steroid glycosides which are commonly used in the health sector. The purpose of this study was to determine the activity of antioxidant compounds from ethanol extracts of Klyxum sp. Klyxum sp., was extracted by maceration using ethanol as a solvent. As a parameter, testing of antioxidant activity was carried out using the DPPH (1,1-diphenil-2-picrylhydarzyl) method, which was measured using UV-Vis spectrophotometry at a wavelength of $517 \mathrm{~nm}$. The results showed that the ethanol extracts of soft coral Klyxum sp., proven to have antioxidant activity in each concentration test.
\end{abstract}

Keywords: Klyxum sp. Soft Coral, Antioxidants, Extraction, DPPH

\begin{abstract}
ABSTRAK
Karang Lunak Klyxum sp. merupakan sumber yang kaya akan senyawa bioaktif seperti terpenoid, steroid, dan steroid glikosida yang biasa dimanfaatkan dalam dibidang kesehatan. Tujuan dari penelitian ini yaitu, untuk mengetahui aktivitas senyawa antioksidan dari ekstrak etanol Karang Lunak Klyxum sp. Karang Lunak Klyxum sp. diekstraksi menggunakan metode maserasi dengan etanol sebagai pelarut. Sebagai parameter, pengujian aktivitas antioksidan dilakukan dengan metode DPPH (1,1-diphenil-2-picrylhydarzyl) yang diukur menggunakan Spektrofotometri UV-Vis pada panjang gelombang $517 \mathrm{~nm}$. Hasil penelitian menunjukkan ekstrak etanol Karang Lunak Klyxum sp. terbukti memiliki aktivitas antioksidan disetiap konsentrasi pengujian.
\end{abstract}

Kata Kunci : Karang Lunak Klyxum sp., Antioksidan, Ekstraksi, DPPH 


\section{PENDAHULUAN}

Tubuh memiliki sistem pertahanan alami untuk menetralisir radikal bebas agar tidak berkembang dan menjadi berbahaya bagi tubuh. Pengaruh lingkungan dan kebiasaan buruk seperti radiasi ultraviolet, polusi, kebiasaan mengonsumsi junk food dan merokok, dapat membuat sistem pertanahan tubuh tidak mampu menghadapi radikal bebas yang berjumlah besar (Silalahi, 2006).

Senyawa radikal bebas merupakan salah satu pemicu kerusakan sel yang dapat menyebabkan penyakit penuaan dan penyakitpenyakit, seperti katarak, penyakit kardiovaskular, kanker, kelainan saraf, inflamasi, diabetes, dan kelainan pencernaan. Senyawa radikal bebas umumnya berbentuk radikal oksigen yang selalu terbentuk di semua sistem biologi yang melibatkan katabolisme oleh oksigen di dalamnya, termasuk sistem organ manusia (Pham-Huy et al., 2008).

Antioksidan berupa senyawa kimia yang dapat menyumbangkan satu atau lebih elektron kepada radikal bebas, sehingga reaksi radikal bebas tersebut dapat terhambat. Penggunaan senyawa antioksidan berkembang dengan pesat, baik untuk makanan maupun pengobatan. Penggunaannya sebagai obat semakin meningkat dengan bertambahnya pengetahuan tentang aktivitas radikal bebas terhadap beberapa penyakit degeneratif seperti penyakit jantung, diabetes, kanker, inflamasi jaringan, kelainan imunitas dan penuaan dini (Jacob dan Burri, 1996).

Berbagai penelitian menunjukan bahwa biota laut memiliki potensi yang sangat besar dalam menghasilkan senyawasenyawa aktif yang dapat digunakan sebagai bahan baku obat. Sejak tahun 1980-an, perhatikan dunia pengobatan mulai terarah ke biota laut yang diketahui dapat menghasilkan senyawa aktif (Ismet, 2007).
Karang lunak merupakan sumber yang kaya akan senyawa bioaktif seperti terpenoid, steroid, dan steroid glikosida. Radhika (2006), dalam penelitiannya melaporkan bahwa sekitar 50\% ekstrak karang lunak menunjukan bahwa metabolit sekunder yang dihasilkan oleh karang lunak memiliki aktivitas biologi seperti antifungal, sitotoksik, antineoplastik, antimikroba, inhibitor HIV dan antiinflamatori.

\section{METODOLOGI PENELITIAN}

\section{Bentuk Penelitian}

Bentuk penelitian yaitu eksperimen laboratorium dengan rancangan penelitian dimana sampel karang lunak Klyxum sp. disiapkan dan diekstraksi dengan metode maserasi menggunakan pelarut etanol kemudian dilakukan uji aktivitas antioksidan terhadap DPPH (1,1-diphenil-2picrylhydarzyl).

\section{Waktu dan Tempat Penelitian}

Penelitian ini dilakukan di Laboratorium Penelitian Farmasi lanjutan (Farmakognosi Fitokimia dan Laboratorium Analisis Farmasi) Program Studi Farmasi, Fakultas Matematika dan Ilmu Pengetahuan Alam, Universitas Sam Ratulangi pada bulan Mei 2019 - Juli 2019.

\section{Alat dan Bahan}

Alat

Alat-alat yang digunakan pada penelitian ini yaitu masker, snorkel, fins, tabung oksigen, kamera, gunting, pisau, wadah botol air kemasan $600 \mathrm{~mL}$, cawan porselin, ziplok, sarung tangan, telenan, gelas ukur, erlenmeyer, baker glass, vortex, corong, mikro pipet, timbangan digital, spatula, oven, spektrofotometer UV-Vis. 


\section{Bahan}

Bahan-bahan yang digunakan pada penelitian ini yaitu karang lunak Klyxum sp., etanol $96 \%$ kertas saring, tissue, alimunium foil, kertas label, serbuk Vitamin C p.a dan serbuk DPPH (1,1-diphenil-2-picrylhydarzyl).

\section{Prosedur Penelitian}

\section{Pengambilan Sampel}

Sampel karang lunak Klyxum sp. diperoleh dari perairan Desa Tumbak, Kecamatan Posumaen, Kabupaten Minahasa Tenggara.

\section{Identifikasi Tanaman}

Identifaksi tanaman dilakukan di Laboratorium Farmakognosi, Program Studi Farmasi, Fakultas Matematika dan Ilmu Pengetahuan Alam, Universitas Sam Ratulangi, Manado.

\section{Ekstraksi}

Sampel direndam dengan menggunakan larutan etanol 96\%. Metode ekstraksi dilakukan dengan cara merendam sampel dengan larutan penyari selama 3 kali 24 jam pada temperatur kamar yang dilindungi dari cahaya dan sesekali dokocok. Kemudian diambil filtratnya dan residu dibuang dan menghasilkan 3 filtrat yang kemudian dicampur menjadi satu. Filtrat tersebut dipekatkan dengan menggunakan oven pada suhu $40^{\circ} \mathrm{C}$ sampai etanol menguap.

\section{Pembuatan Larutan Stok 100 mL}

Sebanyak 100 mg ekstrak etanol karang lunak Klyxum sp. dilarutkan didalam etanol 96\% ad. $100 \mathrm{~mL}$ (konsentrasi 1000 ppm). Dengan masing-masing konsentrasi $100 \mu \mathrm{g} / \mathrm{mL}, 75 \mu \mathrm{g} / \mathrm{L}, 50 \mu \mathrm{g} / \mathrm{mL}$, dan 25 $\mu \mathrm{g} / \mathrm{mL}$ dihitung dengan menggunakan rumus pengenceran, yaitu :

$$
\mathbf{M}_{1} \cdot \mathbf{V}_{1}=\mathbf{M}_{2} \cdot \mathbf{V}_{2}
$$

Pada keempat konsentrasi, masingmasing hasil yang didapatkan dari hasil $\mathrm{V}_{1}$ dipipet dan ditambahkan etanol 96\% hingga mencapai tanda batas (5 mL), kemudian dipindahkan ke dalam tabung reaksi dan ditutup dengan menggunakan aluminium foil untuk digunakan pada perlakuan selanjutnya.

\section{Pembuatan Larutan DPPH}

Penentuan aktivitas penangkal radikal bebas DPPH menurut Burda dan Olezek (2001). Sebanyak 4 mg serbuk DPPH ditimbangdan dilarutkan dalam etanol 96\% sebanyak 100 mL.Selanjutnya larutan stok DPPH dilakukan pengujian kontrol, di uji pada spektrofotometer UV-Vis dengan panjang gelombang antara 400-600 nm.

\section{Pengujian Larutan Kontrol DPPH dan Pengujian Sampel}

Setelah pengujian sampel dan pengujian kontrol, dilanjutkan pada pengujian vitamin C p.a sebagai kontrol pembanding. Kaca arloji ditimbang, vitamin $\mathrm{C}$ ditimbang sebanyak $10 \mathrm{mg}$. Kemudian, vitamin C p.a dilarutkan dalam etanol $96 \%$ sebanyak 10 $\mathrm{mL}$, buat larutan stok dengan konsentrasi yang sama sebelumnya yaitu konsentrasi 100 $\mu \mathrm{g} / \mathrm{mL}, 75 \mu \mathrm{g} / \mathrm{mL}, 50 \mu \mathrm{g} / \mathrm{mL}$ dan $25 \mu \mathrm{g} / \mathrm{mL}$ dengan ditambahkan masing-masing larutan dengan etanol p.a mencapai tanda batas (5 $\mathrm{mL}$ ), dengan pengulangan sebanyak 3 kali pada masing-masing konsentrasi. Pada masing-masing konsentrasi di pipet $2 \mathrm{~mL}$ dan ditambahkan larutan DPPH $2 \mathrm{~mL}$, di vorteks selama 2 menit dan diinkubasi selama 30 menit pada suhu $37^{\circ}$ C. Sampel vitamin C p.a diuji pada spektrofotometer UV-Vis dengan panjang gelombang $517 \mathrm{~nm}$. 


\section{Pengujian Aktivitas Antioksidan dengan metode DPPH}

Penentuan aktivitas penangkal radikal bebas DPPH menurut Burda dan Olezek (2001). Diambil sebanyak $2 \mathrm{~mL}$ ekstrak etanol Karang Lunak Klyxum sp. dengan konsentrasi $100 \mu \mathrm{g} / \mathrm{mL}, 75 \mu \mathrm{g} / \mathrm{mL}, 50 \mu \mathrm{g} / \mathrm{mL}$ dan $25 \mu \mathrm{g} / \mathrm{mL}$ ditambahkan masing-masing 2 $\mathrm{mL}$ larutan DPPH dalam etanol dan divorteks selama 2 menit. Berubahnya warna ungu menjadi warna kuning menunjukkan efisiensi penangkal radikal bebas.Diukur absorbansi pada spektrofotometer UV-Vis dengan panjang gelombang $517 \mathrm{~nm}$ setelah diinkubasi selama 30 menit.Kemudian diamati perbandingannya dengan vitamin $\mathrm{C}$ p.a sebagai standar. Setelah absorbansi didapat, aktivitas penangkapan radikal bebas (persen inhibisi) dihitung sebagai persentase berkurangnya warna DPPH dengan menggunakan rumus berikut:

$$
\% \text { inhibisi }=1-\frac{\text { Absorbansi sampel }}{\text { Absorbansi kontrol }} \times 100 \%
$$

\section{Analisis Data}

Aktivitas antioksidan di ukur dengan menggunakan spektrovotometer UV-Vis kemudian data yang diperoleh disajikan dalam bentuk tabel.

\section{HASIL DAN PEMBAHASAN}

Penelitian ini, sampel yang digunakan adalah Karang Lunak Klyxum sp. Karang Lunak Klyxum sp. dipotong kecil kecil, dikarenakan semakin kecil ukuran sampel, interaksi sampel dengan pelarut semakin besar. Ekstraksi yang dilakukan pada penelitian ini adalah maserasi, dikarenakan maserasi adalah cara ekstraksi yang cukup sederhana hanya membutuhkan wadah perendam dan prosesnya relatif mudah
(Depkes RI, 1986).

Menurut Suryanto

(2012), penambahan pelarut pada suatu bahan harus didasarkan pada sifat kelarutan dari pelarut yang digunakan dan sifat dari komponen yang akan dilarutkan. Senyawa-senyawa yang bersifat polar, cenderung larut dalam pelarut polar sedangkan senyawa-senyawa yang bersifat non-polar cenderung dalam pelarut non-polar.

Pada penelitian ini etanol digunakan sebagai pelarut. Hal ini dikarenakan etanol mempunyai sifat selektif, dapat bercampur dengan air dengan segala perbandingan, ekonomis, mampu mengekstrak sebagian besar senyawa kimia yang terkandung dalam simplisia seperti alkaloida, minyak atsiri, glikosida, kurkumin, kumarin, antrakinon, flavonoid, steroid, damar dan klorofil. Sedangkan lemak, malam, tannin dan saponin, hanya sedikit larut (Depkes RI, 1986). Pelarut etanol juga dipilih karena pelarut ini dapat menyari hampir keseluruhan kandungan senyawa yang ada di dalam simplisia, baik yang bersifat polar, semi polar maupun non polar (Iswanti, 2009).

Tabel 1. Hasil pengujian perbandinganEkstrak Etanol Karang Lunak Klyxum sp. dan Vitamin C p.a

\begin{tabular}{ccccc}
\hline $\begin{array}{c}\text { Ekstrak } \\
\text { dan } \\
\text { Vitamin } \\
\text { C }\end{array}$ & \multicolumn{3}{c}{ PENGULANGAN } & $\begin{array}{c}\text { RATA- } \\
\text { RATA }\end{array}$ \\
\cline { 2 - 4 } & I & II & III & \\
\hline $25 \mu \mathrm{g} / \mathrm{mL}$ & $36.10 \%$ & $36.80 \%$ & $39.50 \%$ & $37.46 \%$ \\
& $91.50 \%$ & $87.30 \%$ & $86.20 \%$ & $89.90 \%$ \\
$50 \mu \mathrm{g} / \mathrm{mL}$ & $46.60 \%$ & $43.30 \%$ & $40.60 \%$ & $42.83 \%$ \\
& $92.70 \%$ & $91 \%$ & $88.20 \%$ & $90.30 \%$ \\
$75 \mu \mathrm{g} / \mathrm{mL}$ & $47.40 \%$ & $43.10 \%$ & $67 \%$ & $52.50 \%$ \\
& $92.80 \%$ & $91.50 \%$ & $88.50 \%$ & $90.93 \%$ \\
$100 \mu \mathrm{g} / \mathrm{m}$ & $51 \%$ & $44.30 \%$ & $71.60 \%$ & $55.63 \%$ \\
$\mathrm{~L}$ & $92.50 \%$ & $92.50 \%$ & $91.60 \%$ & $92.20 \%$ \\
\hline
\end{tabular}


Pengujian aktivitas antioksidan digunakan perbandingan $1: 1$ dimana $2 \mathrm{~mL}$ larutan DPPH dicampurkan dengan $2 \mathrm{~mL}$ larutan sampel (ekstrak etanol karang lunak Klyxum sp. atau vitamin C) pada tiap konsentrasi yang berbeda-beda. Dan campuran DPPH serta ekstrak dilakukan di vorteks selama 2 menit. Menurut Rumagit (2015), berkurangnya intensitas warna larutan DPPH tersebut dapat menunjukan bahwa terjadi reaksi antara atom hydrogen yang dilepas oleh bahan uji dengan molekul radikal DPPH sehingga terbentuk senyawa 1,1difenil-2-pikrihidrazil yang berwarna kuning.

Pengujian aktivitas penangkal radikal bebas ekstrak etanol karang lunak Klyxum sp. dilakukan dengan menggunakan metode DPPH (1,1-diphenil-2-picrylhydarzyl). Pertimbangan dari metode tersebut karena metode DPPH merupakan metode yang relatif mudah, peka dan memerlukan sedikit sampel serta proses pengerjaannya cukup sederhana. Pada metode ini, DPPH bertindak sebagai model radikal bebas yang akan berikatan dengan senyawa penangkap radikal bebas (Simanjuntak et al., 2004). Pengukuran absorbansi dalam penelitian ini dilakukan panjang gelombang maksimum DPPH yang diperoleh, yaitu $517 \mathrm{~nm}$ dengan absorbansi sebesar 0,838. Pengujian dengan menggunakan spektrofotometer UV-Vis dilakukan untuk mengetahui absorbansi DPPH yang tersisa setelah ditambahkan sampel uji dengan berbagai konsentrasi. Jika suatu senyawa memiliki aktivitas sebagai penangkal radikal bebas, maka akan terjadi penurunan nilai absorbasi DPPH pada panjang gelombang maksimum $517 \mathrm{~nm}$. Semakin tinggi konsentrasi, maka nilai absorbansi sampel uji akan menurun dan aktivitas perendaman radikal bebas atau \% inhibisi semakin besar.

Konsetrasi ekstrak etanol karang lunak Klyxum sp. yang digunakan adalah $25 \mu \mathrm{g} / \mathrm{mL}$,
$50 \mu \mathrm{g} / \mathrm{mL}, 75 \mu \mathrm{g} / \mathrm{mL}, 100 \mu \mathrm{g} / \mathrm{mL}$. Masingmasing konsentrasi dicampurkan dengan larutan DPPH dengan perbandingan yang ada. Campuran dihomogenkan dan diinkubasi selama 30 menit pada tempat gelap pada suhu $37^{\circ} \mathrm{C}$. Inkubasi dilakukan untuk menghindari kontaminasi dan mengoptimalkan aktivitas DPPH agar terjadi reaksi antara DPPH dengan sampel yang diuji (Hatano et al., 1998). Setelah diinkubasi, kemudian masing-masing ekstrak dilakukan pengukuran absorbansi menggunakan spektrofotometer pada panjang gelombang serapan maksimum DPPH 517 nm.

Berdasarkan hasil yang diperoleh pada pengujian DPPH persen inhibisi pada ekstrak etanol Karang Lunak Klyxum sp. dan Vitamin C disajikan pada Tabel 1 mengalami peningkatan pada konsentrasi tertinggi yaitu $100 \mu \mathrm{g} / \mathrm{mL}$ yakni $55.63 \%$. Peningkatan persen inhibisi ini pada ekstrak menandakan bahwa semakin besar konsentrasi ekstrak maka semakin besar persen inhibisi. Hal ini didukung oleh penelitian yang dilakukan oleh Hanani et al., (2005) yang menyatakan bahwa presentase penghambatan (persen inhibisi) terhadap aktivitas radikal bebas akan ikut meningkat seiring dengan meningkatnya konsentrasi. Hasil pengujian perbandingan aktivitas antioksidan ekstrak etanol Karang Lunak Klyxum sp. dan Vitamin C menunjukkan bahwa kemampuan penangkal radikal bebas dari Vitamin $\mathrm{C}$ lebih kuat dibandingkan dengan ekstrak etanol Karang Lunak Klyxum sp.

Pembanding yang digunakan dalam penelitian ini yaitu vitamin C. Dimana Vitamin C memiliki aktivitas antioksidan yang tinggi karena vitamin $\mathrm{C}$ memiliki 2 gugus hidroksil yang mengakibatkan lebih mudah dalam pendonoran hidrogen (Blois, 2005). 


\section{KESIMPULAN}

Berdasarkan dari hasil penelitian yang telah dilakukan maka, dapat disimpulkan bahwa ekstrak etanol Karang Lunak Klyxum sp. memiliki aktivitas antioksidan disetiap konsentrasi.

\section{SARAN}

Perlu dilakukan penelitian lebih lanjut untuk mengetahui senyawa aktif yang terkandung dalam ekstrak etanol Karang Lunak Klyxum sp. dan pengujian aktivitas antioksidan dengan metode lain FC (FolinCiocalteu), FRAP (Ferric Reducing Antioxidant Power), RP (Reducing Power) PV (Peroxide Value), TBA (2-thiobarbituric acid) dan sebaiknya membandingkan hasilnya dengan penelitian ini.

\section{DAFTAR PUSTAKA}

Depkes RI. 1986. Sediaan Galenik. Departemen Kesehatan Republik Indonesia, Jakarta.

Ismet, M. S. 2007. Penapisan Senyawa Bioaktif Spons Petrosia sp. dari Lokasi yang berbeda. [Tesis]. Institut Pertanian Bogor, Bogor.

Jacob, R. A., Burri, B. J. 1996. Oxidative Damage and Defense. Am. J. Clin. Nutr. 63: 985S-990S.

Pham-Huy, L.A., Hua, H., dan C. Pham-Huy, 2008, Free Radicals, Antioxidants in Diseases and Health. Int J Biomed Sci. 4(2): 89-96.

Radhika, P. 2006. Chemical constituens and biological activities of the soft coral of genus Cladiella: A review. Biochemical Systematics and Ecological 34: 781-789.
Simanjutak, P., Pratiwi, T., Leny, L. E., Tamat, S. R., Murwani, R. 2004. Isolasi dan Identifikasi antioksidan dari ekstrak Benalu The (Scurrula oortiana (Korth) Danser). Jurnal Ilmu Kefarmasian Indonesia. ISSN : $1693-$ 1831. 5(1): 19-24.

Suryanto, E. 2012. Fitokimia Antioksidan. Penerbit Putra Media Nusantara, Surabaya. 